\title{
Humberto Fernández-Morán (1924-1999) a Pioneer in Electron Ultra-Cryomicroscopy
}

\author{
Humberto Fernández-Morán (1924-1999) Pionero en Ultracriomicroscopía Electrónica
}

Rafael Romero Reverón

ROMERO, R. R. Humberto Fernández-Morán (1924-1999) a pioneer in electron ultra-cryomicroscopy. Int. J. Morphol., 39(6):1782-1786, 2021.

SUMMARY: Humberto Fernández-Morán (1924-1999) a Venezuelan physician and biophysicist research, who developed the diamond knife. Furthermore he focused on improving the mechanical performance, accuracy and reliability of mocrotomes and ultramicrotomes which significantly advanced the development of electromagnetic lenses for electron microscopy based on superconducting technology. Promoter and founded of the Venezuelan Institute for Neurological and Brain Studies. He was a pioneer in electron ultra-cryomicroscopy field. Fernández-Morán taught and researched in University of Stockholm, Massachusetts Institute of Technology, Harvard University, Massachussetts General Hospital and the University of Chicago. He worked with NASA for the Apollo project in the field of physic-chemical analysis of lunar rocks.

KEY WORDS: Humberto Fernández-Morán; Diamond knife; Electron ultra-cryomicroscopy.

\section{INTRODUCTION}

Morphology involves imaging at different length scales, ranging from complete organisms, meters in size, down to single cells with dimensions on the order of micrometers and even nanometer. Consequently, many different techniques are required to visualize morphological and functional processes over this wide range. Subsequently $\mathrm{X}$-rays and the electron were discovered consecutively in the late 19th century, with an electron lens theory introduced at the end of the 1920s. The development of higher resolution microscopes in the early 20th century is a result of using these short wave length beams as the light source. The transmission electron microscope was developed by Ernst Ruska in the early 1930s (Lambert \& Mulvey, 1996). the development of the scanning electron microscope started around the same time as that of the transmission electron microscope. Next, was the scanning transmission electron microscope, which was developed by Manfred Ardenne in the late 1930s, followed by the development of the prototype of the modern scanning electron microscope by Vladimir Zworykin in the early 1940s. Zworykin's prototype however had a low resolution, so scanning electron microscope development continued through projects (Zworykin et al., 1941, 1942).
After 1945 there was an explosion in the biological sciences with the rapid emergence of cell biology, molecular biology and biophysics. These events were affected by the development and use of new technologies for cellular fractionation and imaging, specifically the electron microscope, which provided a resolution unavailable with light microscopes. Electron microscopes made visible the fine structure of cells and their organelles, the structure of viruses and others. Now cryo-electron microscopy is a key tool to visualize and localize the proteins in an entire cell, the organization of actin filaments in the cytoskeleton, and molecular complexes (Curry, 2015). Among several contributors to research in the cryo-electron microscopy field, Humberto Fernández-Morán dedicated to visualize, describe and understand cellular fine structure and from that information, better understand its function through its applications in medicine and biology. In 1953 he developed the diamond knife and its applications for precise cuttings of biological tissues. Fernández-Morán focused on improving the mechanical performance, accuracy and reliability of mocrotomes and ultramicrotomes. The aim of this paper is to provide a brief review about Humberto FernándezMorán's research in electron ultra-cryomicroscopy field. 


\section{Childhood and training in Medicine and Biophysic.}

Humberto Avelino Fernández-Morán Villalobos born on February 18th, 1924, in Maracaibo, Venezuela. His parents were Luis Fernández Morán, a wealthy wood operator and Elena Villalobos. Humberto studied elementary school in New York and later in the German high school in Maracaibo. He eventually moved to Turing, Germany where he finished high school at Schulgemeinde Wichersdorf at 15 years old. Next Humberto Fernández-Morán studied medicine at the University of Munich, where he graduated summa cum laude in 1944 at 20 years of age. He spoke Spanish, German, English and later learned Swedish (Rivas, 2005; Requena, 2011).

He returned to Venezuela and validated his medical studies at the Universidad Central de Venezuela, ranked summa cum laude in 1945.Afterward Humberto Fernández-Morán moved to Washington D.C. between 19451946, where did an internship in Neurologic and Neuropathology at George Washington University (García Tamayo, 2003; Rivas; Esparza \& Padrón, 2018). He became acquainted with the electron microscope during his medical training in Germany and realized its potential as an instrument for the investigation of cellular structures and substructures.

Due to his developing comprehension in the electron microscopy field, he moved to Sweden in 1946 to do training in Neurosurgery at Serafirme Hospital in Stockholm (19461948). He was also a researcher in the electro microcopy area at the Nobel Institute of Physic at the Institute Cellular and Genetic Research, Karoslinska Institute (1947-1949). Fernández-Morán received a master degree in Cell Biology (1948-1951) and his PhD in Biophysics from the University of Stockholm in 1952 (Fernández-Morán, 1948; FernándezMorán \& Luft, 1949; Fernández-Morán, 1950a,1952). At this stage of his life, he began to conceive cryoultramicrotomy and the diamond blade for ultramicrotomy and develop research within electron microscopy field.

\section{Duty in Venezuela}

Humberto Fernández-Morán returned in 1953 to Venezuela where he was promoted to full member of National Academy of Physical, Mathematics and Natural Sciences. The Venezuelan Institute for Neurological and Brain Studies (now the Venezuelan Institute of Scientific Research) was funded in 1954 and Humberto Fernández-Morán was its promoter and first director (Fernández-Morán, 1950b; Soyano \& Müller, 2018). This institute was completed and began research work in December 1955. Initially it was composed of a Neurophysiology department, a unit of diamond blade workshops, a nuclear magnetic resonance laboratory and other research facilities.

In this research institute, Fernández-Morán employed the diamond knife and its applications for precise cuttings of biological tissues (Fernández-Morán, 1953). His first significant results of scientific research, related to the microscopic structure of the retinula of insects, were published in 1956 (Fernández-Morán, 1956; FernándezMorán \& Engoström, 1956). In the following two years (1956-1957), in addition to Fernández Morán, a series of researchers including a neurophysiologist Gunnar Svaetichin and a virologist Gernot Bergold worked at the Venezuelan Institute of Scientific Research.

Fernández-Morán's work was centered on the diamond knife..He worked on the concept of electronic cryomicroscopy, the use of superconducting lenses of liquid helium in electronic microscopes, among much other research. He also helped in the improvement of the ultramicrotomes. In addition, he took electron micrographs of several tissues and intercellular structures, providing some of the first images of biological samples with ultra structural resolution. Fernández-Morán focused on improving the mechanical performance, accuracy and reliability of mocrotomes and ultramicrotomes in order to observe subcellular structures using the diamond knife. In January 1958 due to political plots, Humberto Fernández-Morán resigned to the Venezuelan Institute for Neurological and Brain Studies and left Venezuela.

\section{The diamond knife}

In 1950, Harrison Latta and Francis Hartmann discovered that the edge of broken glass could be used to cut thin sections of specimen (Latta \& Hartmann, 1950). But some hard specimens, such as bone, plants, thick-walled spores, metals and ceramics are difficult to cut, even with a good glass knife, because the edge dulls too quickly. Being involved with electro microscoy since his training in Sweden, Humberto Fernández-Morán developed in 1953 the diamond knife and its applications for precise cuttings of biological tissues (Fernández-Morán, 1953), It is a very sharp knife in which the edge is made from diamond used for medical and scientific applications where an extremely sharp and longlasting edge is essential. The knife's edge is extremely sharp and free of imperfections, which helps produce ultrathin sections of very regular thickness to get views of specimens at high magnifications with the transmission electron microscope.

In the medical field, the use of diamond knives in eye surgery is very common. Scanning electron microscopy 
is used to evaluate and compare the morphology of corneal incisions made with diamond blades designed for eye surgery. The diamond knife cuts smoother leaving the epithelial surface relatively intact and the underlying stroma cleanly separated. Diamond knives were used to make ultrafine cuts in lunar samples brought by astronauts in order to study their composition and morphology (FernándezMorán et al., 1970). For many years, diamond knives produced in Venezuela were provided free of charge to any researcher in the world who requested them by FernándezMorán's resolve.

As a complement to the diamond knife, he designed an ultramicrotome to take full advantage of the diamond blade's features, particularly its ability to produce ultra-fine cuts in both soft and hard specimens. Humberto Fernández-Morán developed the cryo-ultramicrotome that combined his previous diamond knife invention and the ultramicrotome (FernándezMorán, 1957). Particularly important for transmission electron microscope imaging was the development of ultramicrotomy, which allowed ultrathin sections, thus improving resolution and focus. These ultrathin sections allowed researchers to visualize ultrastructural images.

\section{Further research in United States.}

After leaving Venezuela, Humberto FernándezMorán moved to Boston (1958 -1962) to work as associate biophysicist, department of Neurosurgery and Head of the electron microscopy Mixter labs, Massachusetts General Hospital. Simultaneously he was a visiting professor of Biology at the Massachusetts Institute of Technology, and also a research associate in Neuropathology at Harvard University (Rivas; Requena; Esparza \& Padrón).

Fernández-Morán introduced the cryoultramicrotomy in 1953 and then in 1960, the technique of ultra-fast cryofixation with helio liquid. This technique was aimed not only at improving the conditions for the passage of electrons through the specimen, but also at "stopping" the time course of a biological process in action in fractions of a second by instantaneous freezing and thus being able to correlate function with structure (Fernández-Morán, 1962).

The University of Chicago invited Humberto Fernández-Morán to join as full professor of Biophysics in 1962 (Fig. 1). During this period (1962-1968) he worked intensively on high-resolution and low-temperature electron microscopy. .By using superconducting lenses at very low temperatures, an innovation that allowed him to significantly improve the images produced and shorten the exposure time of the specimens under analysis (Fernández-Morán, 1985). The combination of all these improvements and specific developments at the instrument level led him to design the electronic cryomicroscope (Fernández-Morán, 1985, 1986).

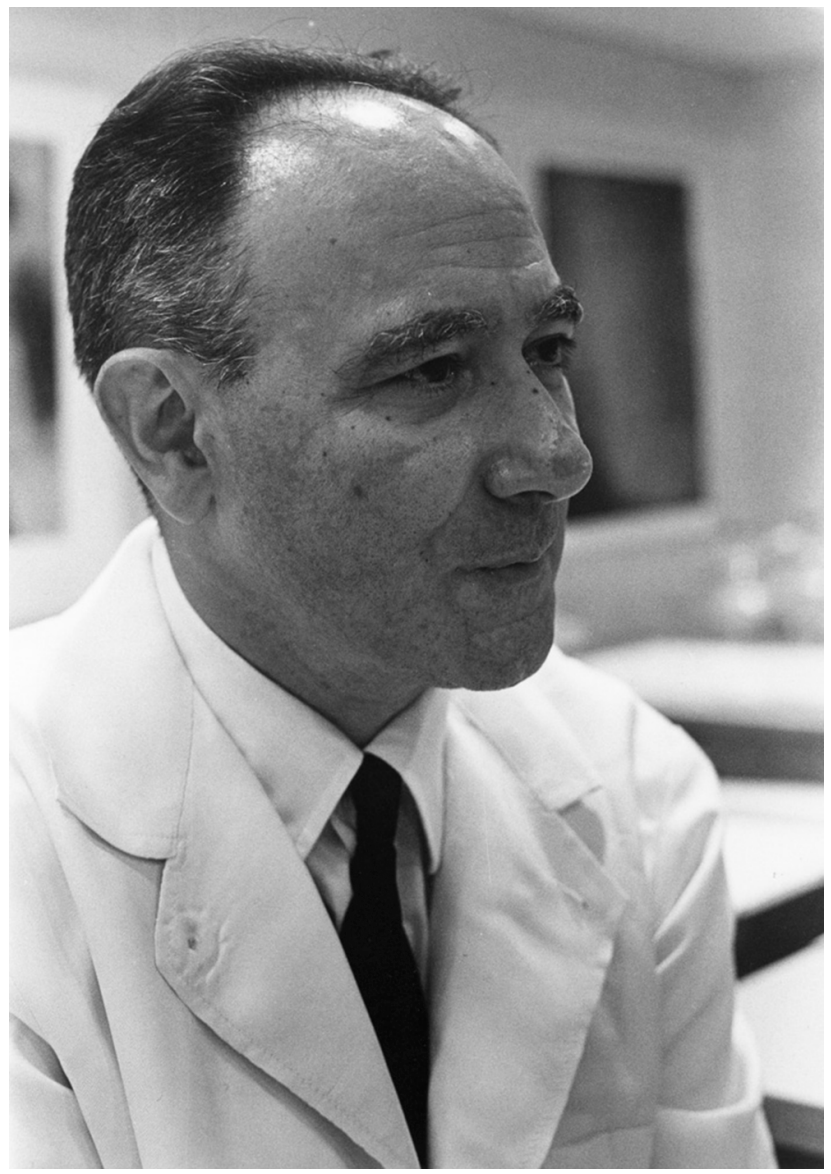

Fig. 1. Humberto Fernández-Morán (1924-1999).

http://photoarchive.lib.uchicago.edu/db.xqy?one=apf1-09746.xml University of Chicago Photographic Archive, [apf digital item number, apf1-09746r.jpg], Special Collections Research Center, University of Chicago Library.

In 1963 Fernández-Morán succeeded in correlating biochemical processes taking place in mitochondrial membranes with electron microscopy images (FernándezMorán, 1963). He cut and studied nervous tissue, the ultrastructure of the myelin sheath, mitochondrial membranes insect retinulae, virus inclusions, bone, embryonic heart. Mosaic viruses, various metals, etc. (Fernández-Morán, 1948, 1950a,b, 1956, 1957; FernándezMorán \& Engoström). In general, his work was morphological and descriptive in nature (Fig. 2). He developed the technique for the separation of samples at low temperatures for electron microscopy, especially biological tissues, which is called cryofixation.

He was also instrumental in the development of the electron microscope, made possible for the first time, the imaging of individual neuronal connections at the 
synaptic level. Both the cryo-ultramicrotome and electron microscope dramatically improved the way that reseaches process and image neural tissue (Fig. 3). In 1966, he built the first electronic cryomicroscope with superconducting lenses at liquid helium temperature at the University of Chicago (Fernández-Morán, 1966).

Later Fernández-Morán was hired at the A.N. Pritzker Professor of Biophysics in the Division of Biological Sciences of the Pritzker School of Medicine in 1967 (Rivas; Requena).

He was selected by National Aeronautics and Space Administration.(NASA) to work on the Apollo Project in the field of physico-chemical analysis of lunar rocks in 1970. Humberto Fernández-Morán made lots of compositional analysis of lunar rock samples brought during the development of the mission. Diamond knives were used to make ultrafine cuts in lunar samples brought by astronauts in order to study their composition and morphology (Fernández-Morán et al.).

In addition he was Head of the laboratories of electron microscopy, electron optics, superconductivity, electron microscopy and superconductivity and superfluid helium at Enrico Fermi Institute in Chicago from 1962 to 1987 (Rivas).

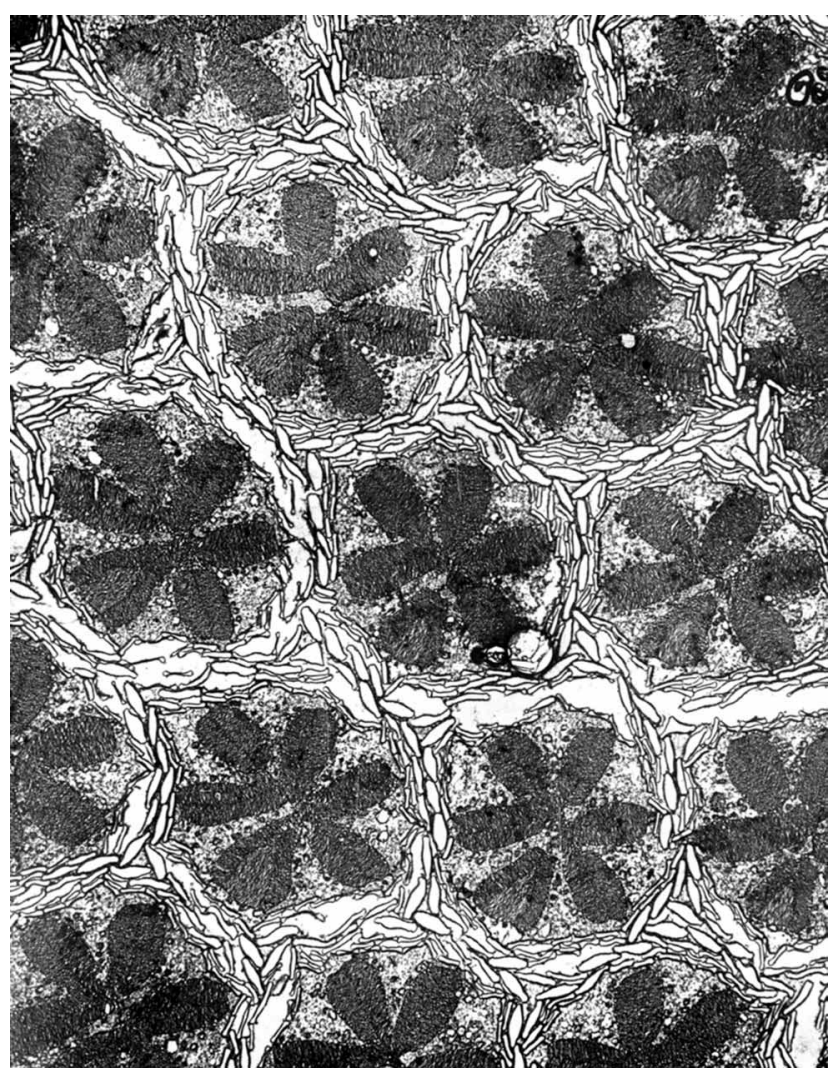

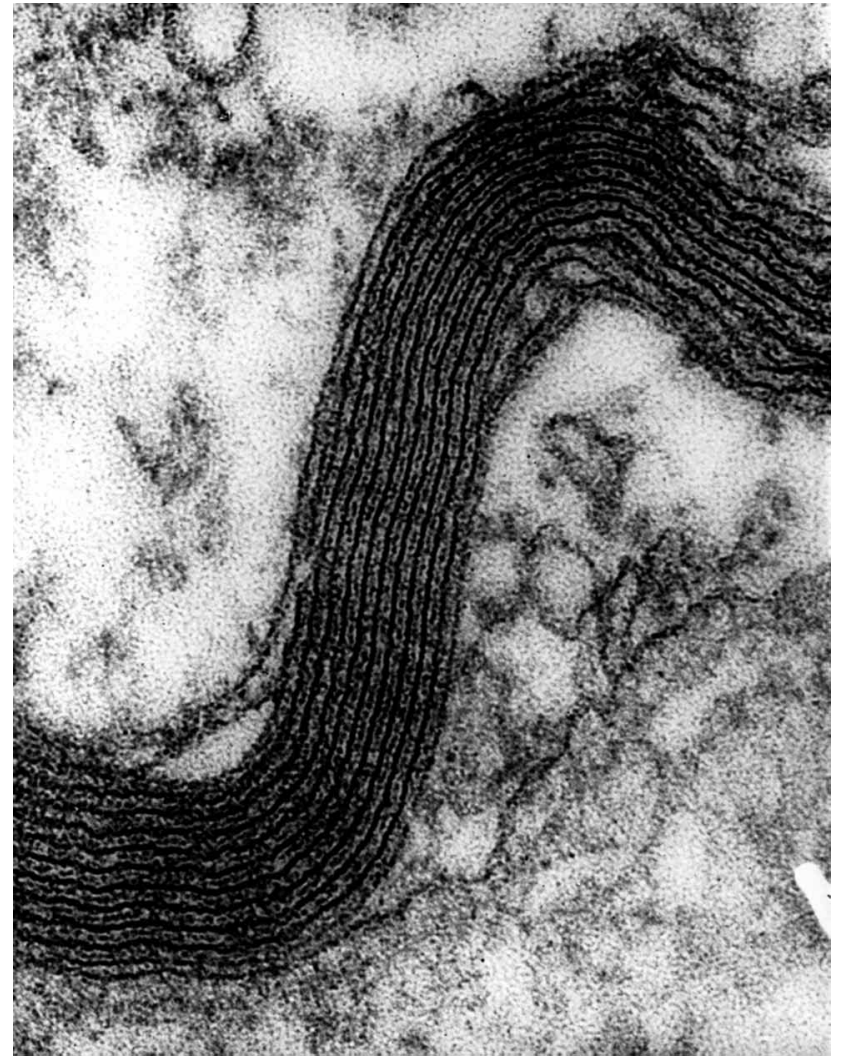

Fig. 3. Fernández-Morán electron micrograph of myelin sheath segment from transverse section of frog sciatic nerve, showing concentric array of dense and intermediate layers. http:// photoarchive.lib.uchicago.edu/db.xqy?one=apf3-01048.xml University of Chicago Photographic Archive,[apf digital item number, apf3-01048.jpg], Special Collections Research Center, University of Chicago Library.

\section{EPILOGUE}

In the late 1980's Humberto Fernández-Morán retired and moved back to Stockholm where he lived with his family. He had married Anna Browallius in 1953. They had two daughters, Brigida Elena (a mathematician) and Veronica (a biologist) and a granddaughter Rossana (Rivas; Esparza \& Padrón). At the end of his life he suffered some strokes. Humberto Fernández-Morán died in March 17,1999 in Stockholm at the age of 75 .

He was dedicated to electron microscopy as a means to visualize, describe and understand cellular fine structure

Fig. 2. Fernández-Morán electron micrograph of a thin segment from the eye of the South American moth Erebus ordora. http:// photoarchive.lib.uchicago.edu/db.xqy?one=apf3-01049. $\mathrm{xml}$ University of Chicago Photographic Archive, [apf digital item number, apf3-01049.jpg], Special Collections Research Center, University of Chicago Library. 
and from that information, better understand its function through its applications in medicine and biology. FernándezMorán developed the diamond knife, as well as being focused on improving the mechanical performance, accuracy and reliability of mocrotomes and ultramicrotomes. Beyond his inventions and pioneering imaging work, his research spanned many fields, including the study of nerve fibers, retina photoreceptors, spinach chloroplasts, oxygen transport, and RNA synthesis in E. Coli (Fernández-Morán, 1956a,b; Fernández-Morán \& Engoström; Fernández-Morán, 1963).

Fernández-Morán was a member of a number of research societies worldwide. He received recognitions for his research including the Claude Bernard Medal from the University of Montreal, Honorary Doctorate from Milton University, the Knight of the Order of the Polar Star, conferred by the Swedish King, the John Scott Medal for his development of the diamond knife (1967), NASA Apollo Project's recognition and the Order del Libertador among others (Rivas; Requena; Esparza \& Padrón).

ROMERO, R. R. Humberto Fernández-Morán (1924-1999) pionero en ultracriomicroscopía electronica. Int. J. Morphol., 39(6):17821786, 2021.

RESUMEN: Humberto Fernández-Morán (1924-1999) médico venezolano e investigador biofísico, quien desarrolló el cuchillo de diamante. Además, se centró en mejorar el rendimiento mecánico, la precisión y la fiabilidad de los micrótomos y ultramicrótomos, lo que avanzó significativamente en el desarrollo de lentes electromagnéticos para microscopía electrónica basados en tecnología superconductora. Promotor y fundador del Instituto Venezolano de Estudios Neurológicos y Cerebrales. Fue pionero en el campo de la ultracriomicroscopía electrónica. Fernández-Morán enseñó e investigó en la Universidad de Estocolmo, el Instituto Tecnológico de Massachusetts, la Universidad de Harvard, el Hospital General de Massachussets y la Universidad de Chicago. Trabajó con la NASA para el proyecto Apollo en el campo del análisis físico-químico de rocas lunares.

PALABRAS CLAVE: Humberto Fernández-Morán; Cuchillo de diamante; Ultracriomicroscopía electrónica.

\section{REFERENCES}

Curry, S. Structural biology: a century-long journey into an unseen world. Interdiscip. Sci. Rev., 40(3):308-28, 2015.

Esparza, J. \& Padrón, R. Un análisis de la obra científica de Humberto FernándezMorán, a los veinte años de su muerte. Gac. Med. Caracas, 126(4):304-25, 2018.

Fernández-Morán H.; Hafner, S.; Ohtsuki, M. \& Virgo, D. Nuclear Gamma Ray Resonat Absorption of $57 \mathrm{Fe}$ and IGH Voltage Electron Microscopy in Pyroxenes from Apollo 11. 1970. Available from: https://www.lpi.usra.edu/ lpi/contribution_docs/LPI-001568.pdf

Fernández-Morán, H. \& Engoström, A. Ultrastuctural organization of bone. Nature, 173:494-5, 1956.
Fernández-Morán, H. \& Luft, R. Submicroscopic cytoplasmic granules in the anterior lobe cells of the rat hypophysis as revealed by electron microscopy. Acta Endocrinol. (Copenh.), 2(3):199-211, 1949.

Fernández-Morán, H. A diamond knife for ultrathin sectioning. Exp. Cell. Res., 5(1):255-6, 1953.

Fernández-Morán, H. A new microtome with the diamond knife. Mikroskopie, 12(3-4):81-8, 1957.

Fernández-Morán, H. Application of the ultrathin freezing sectioning technique to the study of cell structures with the electron microscope. Arkiv. Fysik., 4:471-83, 1952.

Fernández-Morán, H. Cryo-Electron Microscopy and Ultramicrotomy: Reminiscences and Reflections. In: Hawkes, P. W. The Beginnings of Electron Microscopy. Cambridge, Academic Press, 1985. pp.167-223.

Fernández-Morán, H. Examination of brain tumor tissue with the electron microscope. Ark. Zool., 40A:1-29, 1948.

Fernández-Morán, H. Fine structure of the insect retinula as revealed by electron microscopy. Nature, 177:742-3, 1956.

Fernández-Morán, H. High-resolution electron microscopy with superconducting lenses at liquid helium temperatures. Proc. Natl. Acad. Sci. U. S. A., 56(3):801-8, 1966

Fernández-Morán, H. Ideas generales sobre la fundación de un Instituto Venezolano para Investigaciones del Cerebro. Acta Cient. Venez., 1:85-7, 1950b.

Fernández-Morán, H. Megavolt and cryo electron microscopy of diamond knife edges. Ultramicroscopy, 20(3):317-28, 1986.

Fernández-Morán, H. New Approaches in the Study of Biological Ultrastructure by High-Resolution Electron Microscopy. The Interpretation of Ultrastructure, International Society for Cell Biology Symposia, Academic Press, 1962. pp.411-27.

Fernández-Morán, H. Sheath and axon structures in the internode portion of vertebrate myelinated fibers. An electron microscope study of rat and frog sciatic nerve. Exp. Cell. Res., 1:309-40, 1950a.

Fernández-Morán, H. Subunit organization of mitochondrial membranes. Science, 140(3565):381, 1963.

García Tamayo, J. Dr. Humberto Fernández Morán. Legado Científico Invaluable de Venezuela para el Mundo. Caracas, Universidad Central de Venezuela, 2003. Available from: https://caibco.ucv.ve/caibco/vitae/VitaeCatorce/personaje/vitae14personaje.pdf

Lambert, L. \& Mulvey, T. Ernst Ruska (1906-1988), designer extraordinaire of the electron microscope: a memoir. Adv. Imaging Electron Phys., 95:2-62, 1996.

Latta, H. \& Hartmann, J. Use of a glass edge in thin sectioning for electron microscopy. Proc. Soc. Exp. Biol. Med., 74(2):436-9, 1950.

Requena, J. Humberto Fernández Morán (1924-1999). Caracas, El Nacional, 2011.

Rivas, C. Humberto Fernández-Morán de Frente y de Perfil. Caracas, Editorial Arte, 2005.

Soyano, A. \& Müller, A. Humberto Fernández Morán y la creación del Instituto Venezolano de Neurología e Investigaciones Cerebrales (IVNIC, 1954-1959) Rev. Soc. Venez. Hist. Med., 67(1-2), 2018. Available from: https:// revista.svhm.org.ve/ediciones/2018/1-2/art-7/\#

Zworykin, V. K.; Hillier, J. \& Vance, A. W. An electron microscope for practical laboratory service. Electr. Eng., 60(4):157-61, 1941.

Zworykin, V.; Hillier, J. \& Snyder, R. L. A scanning electron microscope. ASTM Bull., 117:15-23, 1942.

Corresponding author:

Rafael Romero

Cátedra de Anatomía Normal

Facultad de Medicina

Escuela de Medicina José María Vargas

Universidad Central de Venezuela

VENEZUELA

Email: rafa1636@yahoo.es

Received: 23-03-2021

Accepted: 18-08-2021 